\title{
Perioperative Local Cooling Reduce Significantly Early Pain after Open Inguinal Hernia Repair: A Prospective Randomized Study
}

\author{
Gerard Champault ${ }^{*}$, Luca Paolino ${ }^{2}$, Antonio Valenti ${ }^{1}$, Christophe Barrat ${ }^{1}$ \\ ${ }^{1}$ Department of Digestive and Metabolic Surgery, Hôpital Jean Verdier, Bondy, France \\ ${ }^{2}$ Pole de Coeliochirurgie, Hopital Joseph Ducuing, Toulouse, France \\ Email: ${ }^{*}$ gerardchampault1@aol.com
}

Received 15 May 2014; revised 20 June 2014; accepted 10 July 2014

Copyright (C) 2014 by authors and Scientific Research Publishing Inc.

This work is licensed under the Creative Commons Attribution International License (CC BY).

http://creativecommons.org/licenses/by/4.0/

(c) (i) Open Access

\section{Abstract}

Pain and local complications are the major determinants of outcome after inguinal hernia repair. To evaluate the respective impact of peri-operative cooling of surgical site and usual care after open inguinal hernia repair, we performed a prospective randomized study. Methods: One hundred and eight consecutive patients with primary unilateral inguinal hernia were included the study. Repair was performed by local direct access during ambulatory surgery. The first study group underwent standard pre- and postoperative local care (control group). In the second group (cold compress group), a single-use disposable sterile cold compress was applied on the surgical site for at least 30 minutes before and 2 hours after surgery. Primary endpoints were immediate postoperative pain using a visual analogue scale, and local complications. Secondary endpoints included: analgesic drug consumption, length of hospital stay, delay to return to normal activity and patient satisfaction. Results: There was no difference concerning operative time $(36.3 \pm 14.0$ vs $39.6 \pm 7.2$ minutes) and early (one-week) complications, although there was a non significant reduced incidence of hematoma and ecchymosis $(0 / 54$ versus $4 / 54)$ for the cold compress group. Analgesic drug consumption was significantly $(p=0.01)$ reduced. During the day of surgery and the first postoperative day, the visual analogue scale was significantly lower after cooling. There was a non-significant reduction in length of hospital stay (150 \pm 37 versus $210 \pm 47 \mathrm{~min})$, and time to return to normal activity was shorter in the cold compress group. Conclusion: For open inguinal hernia repair, immediate pre- and post operative surgical site cooling, targeting a controlled temperature between $12^{\circ} \mathrm{C}$ and $15^{\circ} \mathrm{C}$ significantly reduced postoperative pain, analgesic drug consumption and resulted in improved immediate outcomes. This technique is safe, simple, easy to use, inexpensive and well tolerated by the patient.

${ }^{*}$ Corresponding author.

How to cite this paper: Champault, G., Paolino, L., Valenti, A. and Barrat, C. (2014) Perioperative Local Cooling Reduce Significantly Early Pain after Open Inguinal Hernia Repair: A Prospective Randomized Study. Pain Studies and Treatment, 2, 113-120. http://dx.doi.org/10.4236/pst.2014.23018 


\section{Keywords}

\section{Inguinal Hernia Repair, Cooling, Ambulatory Surgery, Pain, Analgesics}

\section{Introduction}

Hernia surgery performed in the ambulatory setting is widely implemented worldwide, and when performed skilfully, can result in excellent outcomes. Immediate postoperative pain and local complications may, however, negatively affect outcomes. Several studies [1] [2] have shown the benefit of postoperative skin cooling to reduce wound pain and oedema. A number of theories have been put forward to explain the mechanism by which application of an ice pack may attenuate tissue injury and act as a local analgesic. This includes reduction of tissue metabolism and induction of vasoconstriction that may reduce the production of inflammatory cytokines, and reduce oedema and bleeding [3]. Several studies [4] [5] have been performed to establish the critical level of tissue cooling required to induce specific effects; a local temperature of $10^{\circ} \mathrm{C}$ to $12^{\circ} \mathrm{C}$ is needed to lower the tissue metabolic enzyme activity and to reduce nerve conduction velocity.

Our hypothesis was that cold therapy, applied by local sterile frozen ice compress care (Alkantis 180 France) on the surgical site, before and after open inguinal hernia repair, would reduce immediate postoperative pain and bleeding. For this reason, we conducted a prospective randomized trial, comparing treatment with cooling versus standard therapy in patients with primary open unilateral hernia repair.

\section{Patients and Methods}

The Paris XIII University Ethical Committee approved all aspects of the study protocol. Written informed consent was obtained for all patients before enrolment in the trial. The type of local care used was selected at random on the day of surgery.

\subsection{Study Design and Patients}

The device used in the present study (Alkantis 180 France) is a sterile, disposable, polypropylene skin compress, with a small compound and filtrated bag of water $(22 \mu)$, and is ready to use following at least 90-minutes of refrigeration. Compress size is $18 \times 10 \mathrm{~cm}$ and weight is $150 \mathrm{~g}$. The compress can be kept at $-4^{\circ} \mathrm{C}$ (Figure 1 and Figure 2). It is easy to use, fixed by a strap, and provides a dry and sterile cooling (post operative) between $5^{\circ} \mathrm{C}$ and $12^{\circ} \mathrm{C}$ for 2 to 3 hours. It can be prepared several days in advance. Contraindications to use include Raynaud's syndrome, cryoglobulinaemia and allergy to cold.

In the study, patients, from 18 to 65 years of age with primary unilateral inguinal hernia could be enrolled. After informed consent was obtained, the patients were randomized and underwent sutureless Lichtenstein hernia repair.

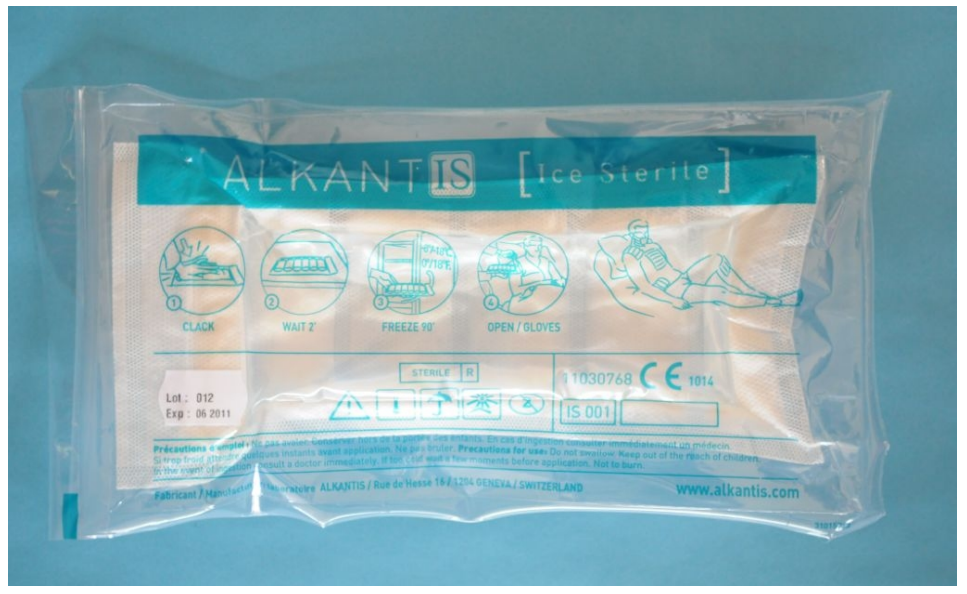

Figure 1. Cold compress ready to use. 


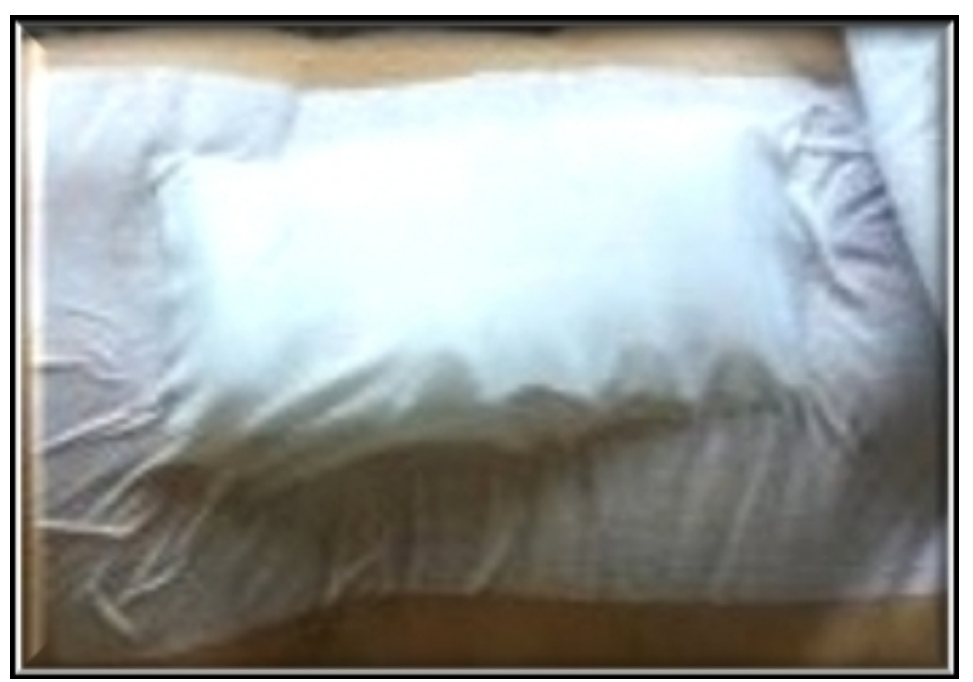

Figure 2. Cold compress during perioperative usage.

Exclusion criteria were: bilateral or recurrent inguinal and femoral hernia, EHS (European Hernia Society) classification [6] L3H3, emergent case, age less than 18-year old, pregnancy, unable to obtain informed consent; peripheral neuropathy, cryoglobulinaemia, Raynaud's syndrome, associated surgery, obesity $\left(\mathrm{BMI} \geq 30 \mathrm{~kg} / \mathrm{m}^{2}\right)$, insulin-dependant diabetes mellitus, hepato-cellular disease, drug or alcohol addiction, psychiatric pathology, regular use of analgesic drugs, steroids, immunosuppressive agents or anticoagulant therapy, contraindication to ambulatory surgery care.

In the treated group, the sterile frozen skin compress was applied on the surgical site starting at least 30 minutes before surgery. It was removed a few minutes prior to skin incision. At the end of the procedure, immediately after skin closure, a second sterile cooling device was placed directly on the surgical site for a minimum of 2 hours.

Preoperative data were collected prospectively, including in a data-base hernia history, demographic characteristic, physical and professional activity level, European Hernia Society (EHS) classification [6], American Society of Anaesthesiologist (ASA) classification, and the presence of co-morbidities and risk factors. Antithrombotic and antibiotic prophylaxis were used according to professional guidelines. The surgical skin site was prepared (shaving, cleaning, antiseptic) in according to hospital protocol. The use of local intra-operative anaesthetic such as Naropeine ${ }^{\circledR}$ (Astra Zeneca France) was not permitted during the trial. Skin was closed with a running absorbable intradermal suture. Analgesic drugs, using the WHO classification was systematically proposed to the patients and used if necessary. The protocole included: Biprofenid ${ }^{\circledR}$, Ketaprofene (Laboratoire Sanofi Aventis France) 100 mg systematically: one pill morning/evening and Ixprim ${ }^{\circledR}$ (Laboratoire Sanofi Aventis France) Tramadol 37.5 mg + Paracetamol 325 mg): 3 pills every day (each 8 hours). Consumption evaluation scale was from 0 to 5 per day (number of pills used by the patient each day).

\subsection{Study End Points}

The primary endpoints were:

1) Pain was assessed during the early hospitalization period (at 2 hours, and before discharge) and after discharge (at home) during the first two postoperative days, at regular time points: 6, 12, 24 and 48 hours post operatively. The evaluation of pain, using a visual analogue scale (VA), was conducted by Unit's nurses during hospitalization - as is the case with all patients who are operated on-and by patients themselves in a self evaluation after having been trained to do so.

2) Early complications (at one week): Ecchymosis, hematoma, skin leakage, wound sepsis, seroma, and mesh infection.

Secondary endpoints were: Operative time and hospital stay (in minutes); uses of the WHO class I-II analgesic drugs during the first two days follow up period, time to return to normal activity, incidence of adverse events, cost savings, patient's satisfaction as determined with a 0 - 100 scale (100 = very satisfied). 


\subsection{Statistical Analysis}

The minimum number of patients in each study group was calculated based on the reduction of pain incidence (during the first two post operative days ) from 21\%, as observed in the literature in the first 48 hours after ambulatory open hernia repair [11] to $5 \%$ or less, would be significant.

With assumption a power test of $80 \%$ and alpha level of 0.05 , we calculated showing that 50 patients were needed in each group study. The final patient number per group was 62 to anticipation of possible "losses".

All statistical analysis was performed using the SAS (version 9.2) software package. The results are reported with $95 \%$ confidence intervals and a $5 \%$ level of significance. Descriptive statistics were used to characterize patient groups, and mean (standart deviation) or median value (range of values) depending of the type of data and a normal data distribution in the interval scale. Qualitative data were summarized using frequency tables (frequency and percentage) and were analysed qualitatively. Frequency distribution was compared using the CHI-square test.

The study was approved by the Hospital Institutional review board, under the control of the Statistical Unit.

\section{Results}

One hundred and twenty five patients were included in the study between September 2010 and December 2011.Incomplete feed back provide by some of them (17:9 in the control group and 8 in the cooling group), demonstrate that the initial population size of 125 was reduced to 108 in order to obtain complete and usable information. The two study groups (54 each) were comparable according to pre- and intraoperative data (Table 1). The study population was composed of 104 males (96\%) and the median age was $53 \pm 15$ years. Mean BMI was $24.6 \pm 3.1 \mathrm{~kg} / \mathrm{m}^{2}$. At admission, 50 patients (47\%) had an ASA score of I, 55 patients (50.9\%) had a score of II and the remaining $2 \%$ had a score of III. The preoperative co morbidity prevalence rate was $10.2 \%$. Forty-two patients (39\%) reported no professional activity (30\% retired and 9\% unemployed), while 38 (36\%) were manual workers and 28 (26\%) had sedentary professional activity. Thirty-four (32\%) reported active participation in sports. The mean duration of the hernia was $1.5 \pm 1.9$ years In accordance with the protocol, all hernias (55 right side, $45 \%$ left side) were defined as primary. The types of hernias, according to the EHS classification, are reported in Table 1.

General anaesthesia was used in $100 \%$ of the cases. The median size incision was $6.3 \pm 1.4 \mathrm{~cm}$ and the mean "skin to skin" operating time was $36.6 \pm 16.8$ minutes. During the surgical procedure, the ilio-inguinal (94\%), ilio-hypogastric (76\%) and genital branch of the genito-femoral (68\%) nerves were observed by the surgeon in 92 patients (85\%). Nerves were preserved in 88 cases) (95.6\%) and cut in 4 cases. The technique performed for hernia repair was the Lichtenstein technique using a self adhering mesh.

According to the study protocol, intra-operative local infiltration of buvicaïne (Naropeine ${ }^{\circledR}$ : Astra Zeneca)

Table 1. Pre operative data.

\begin{tabular}{|c|c|c|c|}
\hline & Cooling & No Cooling & p-Value \\
\hline Number N & 54 & 54 & ns \\
\hline Male/Female & $53 / 1$ & $51 / 3$ & ns \\
\hline Age (Years) & $52 \pm 9.7$ & $54 \pm 8.2$ & ns \\
\hline Co-Morbidity (\%) & 6/54 (11.1\%) & $5 / 54(9.2 \%)$ & ns \\
\hline ASA Score I & 23 & 27 & ns \\
\hline Score II & 28 & 27 & ns \\
\hline BMI Index $\left(\mathrm{kg} / \mathrm{m}^{2}\right)$ & $25.4 \pm 4.1$ & $23.4 \pm 3.7$ & ns \\
\hline $\begin{array}{c}\text { Professional Activity } \\
\text { No (Retired/Jobless) } \\
\text { Manual Work } \\
\text { Sedentary }\end{array}$ & $\begin{array}{l}21 \\
18 \\
15\end{array}$ & $\begin{array}{l}21 \\
20 \\
13\end{array}$ & $\begin{array}{l}\text { ns } \\
\text { ns } \\
\text { ns }\end{array}$ \\
\hline $\begin{array}{l}\text { Type of Hernia (EHS) } \\
\text { 1. L.P } \\
\text { 1. M.P } \\
\text { 2. L.P } \\
\text { 2. M.P }\end{array}$ & $\begin{array}{c}7 \\
14 \\
8 \\
25\end{array}$ & $\begin{array}{c}6 \\
12 \\
6 \\
30\end{array}$ & $\begin{array}{l}\text { ns } \\
\text { ns } \\
\text { ns } \\
\text { ns }\end{array}$ \\
\hline
\end{tabular}


was not performed. According to professional recommendations, the patients did not receive any prophylactic antibiotics or anticoagulation. There were no intraoperative complications.

There was no difference regarding the operative time ( $36.3 \pm 14 \mathrm{~min}$ vs $39.6 \pm 7.2 \mathrm{~min}$ ) between the study groups. Hospital stay was not significantly reduced in the experimental group (150 $\pm 37 \mathrm{~min}$ vs $210 \pm 47 \mathrm{~min})$. The rate of early local complications (one week) was comparable, although there were fewer hematomas and decreased ecchymosis in the treated group ( $0 / 54$ versus $4 / 54$; (ns). There was no sepsis or skin leakage. Analgesic drug consumption (analgesic/anti-inflammatory, scoring between 0 to 5 ) was significantly ( $p=0.01$ ) reduced in the treated group during the first two post-operative days (Table 2), with a significantly lower VAS pain score, at the different time points (6, 12, 24 and 48 hours) (Table 3). In the treated group, 90\% of the patients had no pain (VAS $=0)$ on the first day after surgery: this percentage was significantly $(p=0.01)$ higher than in the control group. The mean VAS was significantly lower, with less analgesic drug consumption $(p=0.01)$. These findings were similar on the second post operative day. The percentage of patients returning to normal activity was higher in the treated group (8 questions with answer "yes or not" at day 1 and day 2) (Table 4). None of the treated patient displayed "side effects" and all patients were very satisfied (ns) in the two groups ( $97 \pm 2.6$ vs $95 \pm 4.1$ ). Lastly, use of the cold compress did not had any significant additional cost in the French Health System.

\section{Discussion}

Lichtenstein's technique for inguinal hernia repair is recognized as an efficient and safe method with a low recurrence rate, and is considered the "Gold Standard" [7], performed in the ambulatory surgery setting. BayNielsen et al. [8] have pointed to early and long-term pain as major adverse outcomes after hernia repair. Numerous contributing factors have been described. Recently, we have shown in a prospective study using the principles of the Lichtenstein technique, the safety and efficacy of a "self adhering" mesh (lightweight $32 \mathrm{~g} / \mathrm{m}^{2}$ ) coated with restorable chemical glue in terms of early outcomes [9].

We routinely used this prosthesis for patients included in the trial. Ambulatory hernia surgery is recommended in the EHS guidelines [7] Outcomes after ambulatory surgery are correlated with the risk of early complications, specifically bleeding (hematoma) and the possibility of uncontrolled pain, during the first two postoperative days. Inguinal hernia repair is a painful ambulatory surgery, with almost half of patients describing moderate to severe pain post-operatively [10]. The incidence of severe pain was evaluated to be $21 \%$ in the first 48-hours post ambulatory surgery [11] and pain control has been shown to improve postoperative recovery [12]. Also, poor pain control can lead to the development of chronic pain. Several pain control methods have been suggested including: use of analgesic drugs (antalgic, anti-inflammatory), and intraoperative infiltration of

Table 2. Use of analgesic drugs (during the first and second post operative days).

\begin{tabular}{|c|c|c|c|c|c|}
\hline & \multicolumn{2}{|c|}{$\begin{array}{c}\text { Cooling } \\
\mathrm{N}=54\end{array}$} & \multicolumn{2}{|c|}{$\begin{array}{c}\text { No cooling } \\
\mathrm{N}=54\end{array}$} & \multirow[t]{2}{*}{$\mathrm{p}$-value } \\
\hline & Patients ${ }^{1}$ & Pills $^{2}$ & Patients ${ }^{1}$ & Pills $^{2}$ & \\
\hline Day 1 & $22 / 54(44 \%)$ & 1.6 & $42 / 44(77 \%)$ & 2.3 & $p=0.01$ \\
\hline Day 2 & $34 / 54$ (62\%) & 2.1 & 41/54 (75\%) & 3.1 & $p=0.01$ \\
\hline
\end{tabular}

Patients $^{1}$ : number and percentage using Analgesic drugs; Pills ${ }^{2}$ : mean use per day (scoring 0 - 5) for patients using analgesic drugs.

Table 3. Evaluation of pain (VAS) (during the first two post operative days).

\begin{tabular}{cccccc}
\hline & \multicolumn{2}{c}{ Cooling $(\mathrm{N}=54)$} & \multicolumn{2}{c}{ No cooling $(\mathrm{N}=54)$} & \multirow{2}{*}{$\mathrm{p}$-value } \\
\cline { 2 - 5 } VAS $(0$ to 100$)$ & Mean & $(\mathrm{VAS}=0)$ & Mean & \multicolumn{1}{c}{$(\mathrm{VAS}=0)$} & \\
Return Ambu unit & $3.1(0-18)$ & $49(90 \%)$ & $11.2(0-41)$ & $41(76 \%)$ & $\mathrm{ns}$ \\
Postop: 2 hours & $3.4(0-17)$ & $47(87 \%)$ & $18.4(0-52)$ & $36(66 \%)$ & $\mathrm{p}=0.01$ \\
Leaving hospital & $4.6(0-24)$ & $47(87 \%)$ & $19.6(0-48)$ & $28(51 \%)$ & $\mathrm{p}=0.01$ \\
Postop: 6 hours & $12.7(0-31)$ & $38(70 \%)$ & $29.4(0-60)$ & $10(18.5 \%)$ & $\mathrm{p}=0.02$ \\
12 hours & $19.8(0-34)$ & $18(33 \%)$ & $24.3(11-45)$ & $0(0 \%)$ & $\mathrm{p}=0.01$ \\
24 hours & $14.2(0-21)$ & $14(25 \%)$ & $21.7(17-52)$ & $0(0 \%)$ & $\mathrm{p}=0001$ \\
48 hours & $10.2(0-31)$ & $23(42.5 \%)$ & $19.6(0-53)$ & $8(14.8 \%)$ & $\mathrm{p}=0.01$ \\
\hline
\end{tabular}

VAS: mean and range at each control; VAS $=0$ : number of patients and percentage. 
Table 4. Return to normal activity.

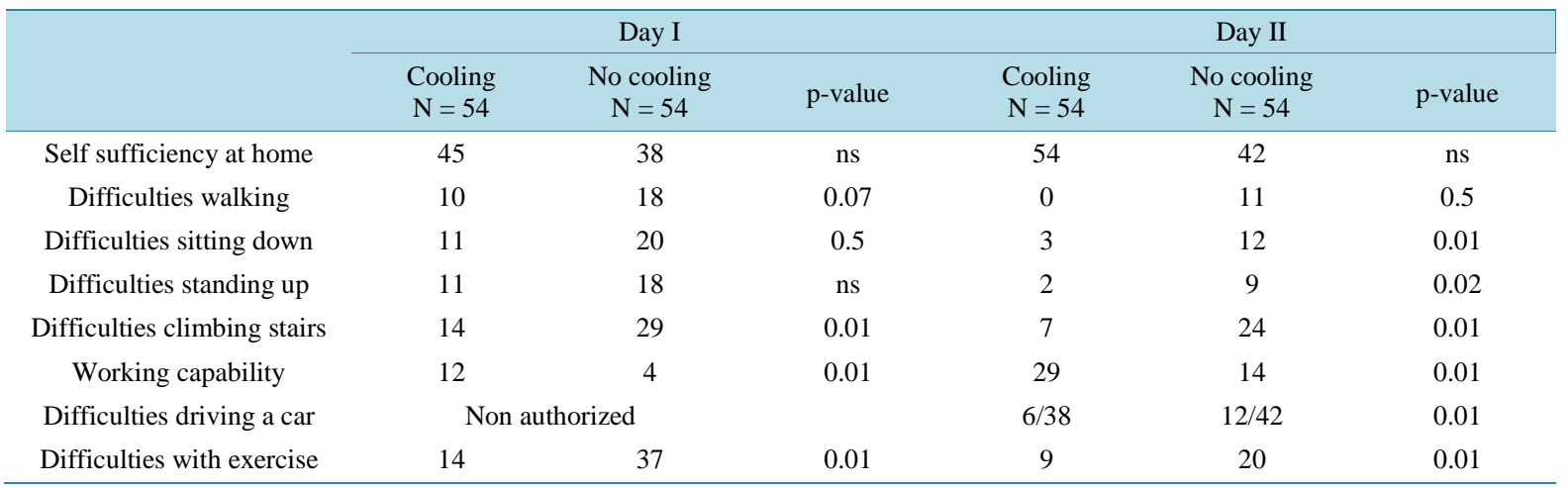

Number of patients with positive answer to the question.

xylocaïne [7]. Current therapeutic strategies for the management of postoperative pain management are mostly dependent on opioid analgesics and NSAIDs. Placebo-controlled studies have shown that NSAIDs reduce postoperative pain and limit the use of additional analgesics after inguinal hernia repair [13]. Administration of a COX-2 selective non steroidal anti-inflammatory drug prior and following outpatient inguinal herniorraphy improves functional outcomes when compared with placebo and increases patient satisfaction yet the use of COX inhibitors is associated with thrombotic complications [14]. The risk profile for COX-2 selective agents in terms of cardiovascular and renal systems requires a careful patient selection. The administration of local anaesthetic agents into the surgical incision and surrounding wound bed is easy to perform and is low risk for patients. Pain ratings and opioid requirements are reportedly decreased following a single dose wound infiltration of a long acting local anaesthetic following inguinal herniorraphy, when compared to saline infiltration [15]. Cryotherapy is a widely used technique in the immediate care of traumatic injury, protocols for postsurgical rehabilitation and treatment of pain [4]. A number of studies have been performed to establish the critical level of tissue cooling $\left(13.6^{\circ} \mathrm{C}\right)$ required for specific effects (localized analgesia). To reduce nerve conduction velocity by approximately $10 \%$, a temperature of $12.5^{\circ} \mathrm{C}$ is required and to lower metabolic enzyme activity by approximately $50 \%$, a tissue temperature between $10^{\circ} \mathrm{C}$ and $11^{\circ} \mathrm{C}$ is suggested [16] [17]. Historically, gel packs have been criticized for being too stiff when frozen and therefore, unable to shape adequately to the body part on application. This lack of flexibility reduces the cooling effect, because the modality is not uniformly in contact with the skin. Alkantis $180^{\circledR}$, used in the present study, is a sterile device, usable for postsurgical wound care, supple, covering exactly $(18 \times 12 \mathrm{~cm})$ of the surgical site needed for inguinal open hernia repair, overcoming the above mentioned disadvantage. The temperature measurements showed that the effective level of cooling $\left(10^{\circ} \mathrm{C}-12^{\circ} \mathrm{C}\right)$ was obtained in about 30 minutes. Postoperatively, the cooling device (sterile) should be used during the entire rehabilitation period before living hospital. The tolerance was acceptable in $100 \%$ of the patients (weight $180 \mathrm{~g}$ ) with a high level of satisfaction concerning pain control (95\%).

Several investigators have reported intramuscular (IM) temperature at specific depths relative to subcutaneous adipose layer [18] [19]. With a 30-minute ice bag application to the thigh, $1 \mathrm{~cm}$ subadipose IM temperature has been reported to decline by $9.7^{\circ} \mathrm{C}$, whereas $2 \mathrm{~cm}$ subadipose IM temperature reduction of $5^{\circ} \mathrm{C}$ and $8.4^{\circ} \mathrm{C}$ has been reported [20]. Thus, cooling of the operating site may be inefficient in obese patient. We speculate that adequate cooling may require a longer application time for obese patients.

In the present study, we recorded no adverse events in the treated group. Pain evaluated by VAS during and after the hospital stay, was decreased at all time points for the compress group. Furthermore, consumption of analgesic drugs was significantly reduced in the same group during the first two days after surgery. Patients were discharged from the ambulatory unit earlier (ns) than in the control group, and displayed a significantly (p $=0.01$ ) better rehabilitation at home with earlier return to daily activities. Our results are in keeping with prior studies reported in the literature [20]. The effects of cooling have been also evaluated in a randomized trial using local anaesthesia for ambulatory hernia repair in the UK [21], with a significant reduction of pain after cooling of the operative site $\left(4^{\circ} \mathrm{C}\right.$ versus $\left.22^{\circ} \mathrm{C}\right)$ for 5 minutes. Simultaneously, there is a risk of local tissue necrosis at this level of cooling. Although relatively unfrequent, groin hematoma following inguinal herniorraphy is a morbid complication with significant ramifications including mesh infection and hernia recurrence. Smooth et al. 
[22] have shown that the crucial risk factor for groin hematoma for patients undergoing inguinal hernia repair is the preoperative Coumadin therapy. In this situation, local cooling may reduce the risk of hematoma. Patients on Coumadin therapy were excluded from the present trial. Application of the ice compress did not add additional expense to the patient's care in the French Health system, and may have reduced the possible side effects of antalgic drugs.

\section{Conclusion}

In open hernia repair, preoperative cooling of the operative site for 20 to 30 minutes, using the gel compress $\mathrm{Al}$ kantis $180^{\circledR}$ significantly decreases early postoperative pain, resulting in a reduction of antalgic drug use. This approach is simple, easy to use, well tolerated, no-expensive, and safe. This cooling technique could be a reasonable alternative to intraoperative analgesic infiltration (dose related, allergies) and/or systematic use of analgesic drugs, which may have adverse effects.

\section{Conflict of Interest}

Summative Disclosure Statement:

- Gerard Champault declares conflict of interest directly related to the submitted work (Travel support, meeting registration);

- Antonio Valenti declares no conflict of interest;

- Luca Paolino declares no conflict of interest;

- Christophe Barrat declares no conflict of interest.

\section{References}

[1] Collins, N.C. (2008) Is Ice Right? Does Cryotherapy Improve Outcomes for Acute Soft Tissue Injury? Emergency Medicine Journal, 25, 65-68. http://dx.doi.org/10.1136/emj.2007.051664

[2] Hubbard, T.J. and Denegar, C.R. (2004) Does Cryotherapy Improve Outcomes with Soft Tissue Injury? Journal of Athletic Training, 39, 278-279.

[3] Abramson, D.I., Chu, L.S., Tuch Jr., S., Lee, S.W., Richardson, G. and Levin, M. (1966) Effect of Tissue Temperature and Blood Flow on Motor Nerve Conduction Velocity. JAMA, 198, 1082-1088. http://dx.doi.org/10.1001/jama.1966.03110230098021

[4] Chesterton, L.S., Foster, N.E. and Ross, L. (2002) Skin Temperature Response to Cryotherapy. Archives of Physical Medicine and Rehabilitation, 83, 543-549. http://dx.doi.org/10.1053/apmr.2002.30926

[5] Zachariassen, Z.E. (1991) Hypothermia and Cellular Physiology. Arctic Medical Research, 50, 13-17.

[6] Miserez, M., Alexandre, J.H., Campanelli, G.P., Corcione, F., Cuccurullo, D., Hidalgo Pascal, M., et al. (2007) The European Hernia Society Groin Hernia Classification: Simple and Easy to Remember. Hernia, 11, 113-116. http://dx.doi.org/10.1007/s10029-007-0198-3

[7] Simons, M.P., Angenacker, T., Bay Nielsen, H., Bouillot, J.L., Campanelli, G.P., Conze, J., et al. (2009) European Hernia Society Guidelines on the Treatment of Inguinal Hernia in Adult Patients. Hernia, 13, 343-403. http://dx.doi.org/10.1007/s10029-009-0529-7

[8] Bay Nielsen, H., Perkins, F.M. and Kehlet, H. (2001) Danish Hernia Data Base: Pain and Functional Impartment 1 Year after Inguinal Herniorraphy: A Nationwide Questionnaire Study. Annals of Surgery, 233, 1-7. http://dx.doi.org/10.1097/00000658-200101000-00001

[9] Champault, G., Torcivia, A., Paolino, L., Chaddad, W., Lacaine, F. and Barrat, C. (2011) A Self Adhering Mesh for Inguinal Hernia Repair: Result of a Prospective Multicentric Study. Hernia, 15, 635-641. http://dx.doi.org/10.1007/s10029-011-0843-8

[10] McGrath, B., Elgendy, H., Chung, F., Kamming, D., Curti, B. and King, S. (2004) Thirty Percent of Patients Have Moderate to Severe Pain $24 \mathrm{~h}$ after Ambulatory Surgery: A Survey of 5703 Patients. Canadian Journal of Anaesthesia, 51, 886-891. http://dx.doi.org/10.1007/BF03018885

[11] McHugh, G.A. and Thoms, G.M. (2002) The Management of Pain Following Day-Case Surgery. Anaesthesia, 57, 270-275. http://dx.doi.org/10.1046/j.1365-2044.2002.2366 2.x

[12] Ready, L.F. (1990) Patient Controlled Analgesia : Does It Provides More than Comfort? Canadian Journal of Anaesthesia, 37, 719-721. http://dx.doi.org/10.1007/BF03006527

[13] Mentes, O. and Bager, M. (2009) Post Operative Pain Management after Inguinal Hernia Repair: Lornoxicain versus 
Tramadol. Hernia, 13, 427-430. http://dx.doi.org/10.1007/s10029-009-0486-1

[14] Schun, M.J. and Faucher, L.D. (2009) A Prospective Randomized, Comparative Trial of a Cox-2 Selective Non Steroidal Anti-Inflammatory Drug versus Placebo in Inguinal Herniorraphy Patients. Hernia, 13, 491-497. http://dx.doi.org/10.1007/s10029-009-0489-y

[15] Peterson, N. and Emanuelson, B.M. (1998) High Dose Ropivacaine Wound Infiltration for Pain Relief after Inguinal Hernia Repair. A Clinical and Pharmacokinetic Evaluation. Regional Anesthesia and Pain Medicine, 23, 189-196. http://dx.doi.org/10.1097/00115550-199823020-00013

[16] Barnard, D. (1980) The Effects of Extreme Cold on Sensory Nerves. Annals of the Royal College of Surgeons of England, 62, 182-187.

[17] McMeeken, J., Murray, L. and Cocks, S. (1984) Effect of Cooling with Stimulated Ice on Skin Temperature and Nerve Conduction Velocity. Australian Journal of Physics, 30, 111-114.

[18] Wotte, J., Menick, M.A., Ingersoll, C.D. and Cordoca, M.L. (2002) Subcutaneous Adipose Tissue Thrickness Alters Cooling Time during Cryotherapy. Archives of Physical Medicine and Rehabilitation, 83, 1501-1505. http://dx.doi.org/10.1053/apmr.2002.34833

[19] Jutte, L.S., Merrick, M.A., Ingersill, C.D. and Edwards, J.E. (2001) The Relationship between Intramuscular Temperature, Skin Temperature and Adipose Thickness during Cryotherapy and Rewarming. Archives of Physical Medicine and Rehabilitation, 82, 845-850. http://dx.doi.org/10.1053/apmr.2001.23195

[20] Koc, M., Tez, M., Yoldas, O., Dizen, H. and Goemen, E. (2006) Cooling for the Reduction of Post Operative Pain: Prospective Randomized Study. Hernia, 10, 184-186. http://dx.doi.org/10.1007/s10029-005-0062-2

[21] Leff, D.R., Worthley, M., Dong, V. and Bhutiani, R.P. (2007) The Effect of Local Cooling on Pain Perception during Infiltration of Local Anesthetic Agents; a Prospective Randomised Controlled Trial. Anaesthesia, 62, 677-682. http://dx.doi.org/10.1111/j.1365-2044.2007.05056.x

[22] Smoo, R.L.T., Oderich, G.S., Tana, C.B., Creenlie, S.M., Larson, D.R., Cragum, E.B. and Farley, D.R. (2008) Post Operative Hematoma Following Inguinal Herniorraphy: Patient Characteristics Leading the Increased Risk. Hernia, 12, 261-265. http://dx.doi.org/10.1007/s10029-007-0313-5 
Scientific Research Publishing (SCIRP) is one of the largest Open Access journal publishers. It is currently publishing more than 200 open access, online, peer-reviewed journals covering a wide range of academic disciplines. SCIRP serves the worldwide academic communities and contributes to the progress and application of science with its publication.

Other selected journals from SCIRP are listed as below. Submit your manuscript to us via either submit@scirp.org or Online Submission Portal.
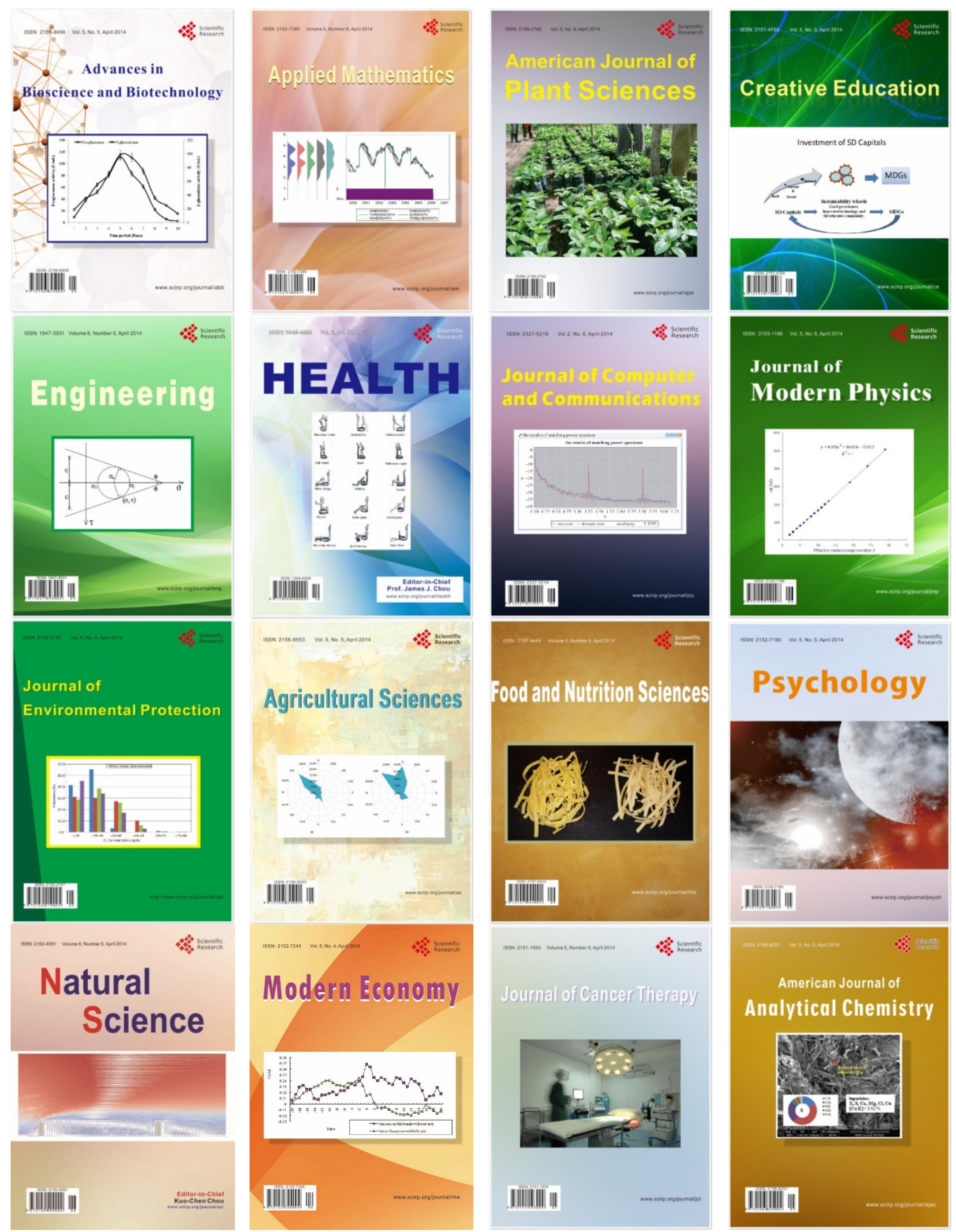